\title{
The Effect of Cinnamon on Microbiological, Chemical and Sensory Analyses of Probiotic Yogurt
}

\author{
(D) Ayşe GÜNEŞ BAYIR, id Mehmet Gültekin BİLGIN
}

Bezmialem Vakif University, Faculty of Health Sciences, Department of Nutrition and Dietetics, Istanbul, Turkey

\begin{abstract}
Objective: This study was performed with the aim of determining the effects of different levels of cinnamon which were added to probiotic yogurts on the microbiological, chemical and sensory properties of these yogurts.

Methods: In this study, probiotic yogurt was produced using yogurt and probiotic yogurt cultures. Yogurts are divided into four groups; control, cinnamon 1, cinnamon 2 and cinnamon 3 groups. To the groups, $0 \%, 0.3 \%, 1 \%$ and $2.5 \%$ of powdered cinnamon were added, respectively. Content analysis of cinnamon used in the study was conducted by gas chromatography- mass spectrometry method.

Results: The addition of cinnamon to probiotic yogurt showed antibacterial activity on Streptococcus thermophilus, Lactobacillus acidophilus and Bifidobacterium animalis ssp. lactis while cinnamon depending on its concentration was found to support bacterial growth of Lactobacillus delbrueckii subsp. bulgaricus. The $\mathrm{pH}$ values and the fat-free dry matter ratios varied depending on the proportion of cinnamon added to the yogurts. When the sensory characteristics of yogurt were compared, the score of the control group was higher than the score of cinnamon groups. On the other hand, cinnamon (1\%) group had the closest score to the sensory analysis score of the control group.

Conclusion: These results have shown that cinnamon added at different ratios in probiotic yogurt has a limited positive effect on the microbial, chemical and sensory properties of this food.
\end{abstract}

Keywords: Cinnamon, functional food, probiotic yogurt, probiotic bacteria, yogurt bacteria

\section{Introduction}

Probiotics are available in the market as food and nutritional supplements. Probiotics, as functional food group, play a role in protection and development of health, and treatment of diseases. Probiotics are recommended especially in cases of gastrointestinal disorders, atopic dermatitis and food intolerance (1). Probiotic has been described as a "living microbial dietary supplement" that positively affects the host's intestinal pathways (2). Probiotic bacteria boost the immunity in individuals as well as reduce fecal enzymes and mutagenicity. The nutritional sources of probiotics include fermented foods such as yogurt, kefir, cheese, pickles and raw sausage, which contain probiotic bacteria and/or yeasts (3). The probiotic property of a food is based on its medical activity, the number of active cells or the total number of living cells per $\mathrm{mL}$ (4). A probiotic food must contain at least $1.0 \times 10^{6}$ colonyforming units (cfu)/g of living probiotic microorganisms (5).

Yogurt has an important role in our nutrition but also has a therapeutic role in the protection and development of health (6). Yogurt is briefly defined as a clot formed by fermentation and precipitation of milk proteins (7). Yogurt is traditionally produced by fermentation of Streptococcus thermophilus and Lactobacillus delbrueckii ssp. bulgaricus starter culture (8). Most of the classic

Address for Correspondence: Ayşe GÜNEŞ BAYIR, Bezmialem Vakif University Faculty of Health Sciences, Department of Nutrition and Dietetics, İstanbul, Turkey

Phone: +90 21240126 00-4596 E-mail: agunes@bezmialem.edu.tr ORCID ID: orcid.org/0000-0002-9993-7850 
yogurt cultures used in the fermentation of yogurt are unable to survive in the intestines after individuals consume the yogurt due to its low $\mathrm{pH}$ value (9). Therefore, prophylactic use of yogurt is limited. However, on the other hand, this limitation encourages the production of different types of yogurts with different starter culture formulations. In particular, the use of probiotic cultures consisting of Lactobacillus acidophilus and bifidobacteria in yogurt production is increasing (10). Thus, yogurt gains prophylactic and therapeutic value. Vitamins and enzymes produced by lactic acid bacteria contribute to host metabolism, while antimicrobial agents produced control the proliferation of undesired pathogens in the host (6). It has been reported in several studies that these bacteria and other probiotic bacteria possess tumor suppression properties by reducing mutagenic, carcinogenic and genotoxic components in colorectal cancer, which is the third most common cancer in the world (11).

Cinnamon (Cinnamomum) is derived from a tree belonging to the family Lauraceae. In studies, antioxidant, insecticide, antidiabetic, anti-inflammatory, anti-thrombosis and analgesic effects of cinnamon have been reported (12). Many studies have shown that the components of cinnamon oil or its extract has an inhibitory effect on pathogenic microorganisms by $75-100 \%$ (13). Cinnamon as the main component of , cinnamaldehyde, has antibacterial properties by inhibiting the synthesis and function of bacteria cell wall, the synthesis of nucleic acid and protein. The shelf life of the product was investigated in a study conducted by adding different amounts of cinnamon powder $(0.3 \%, 1 \%$ and $2.5 \%)$ to pasteurized milk (14). In this study, it was determined that the number of lactic acid bacteria in milk, in which cinnamon was added, was low compared to the control group in which cinnamon was not added. In another study, powder cinnamon in different concentrations did not have an antibacterial effect on Staphylococcus aureus, because the buffering capacity of milk and yogurt neutralized the acidity of cinnamon (15). But powdered cinnamon has had a positive effect on the sensory quality of milk and yogurt.

In this study, probiotic yogurts with cinnamon added in different proportions were produced and the effect of cinnamon on microbiological, chemical and sensory properties of these yogurts was investigated.

\section{Method}

\section{GC-MS Analysis of Cinnamon}

Cinnamon was obtained from Bezmialem Vakif University, Phytotherapy Center (Istanbul, Turkey) and the chemical components of cinnamon were analyzed using gas chromatography-mass spectrometry (GC-MS) (Agilent 5977A, USA) method. The GC-MS system used provided these conditions: Injection volume $(5 \mu \mathrm{L})$, inlet temperature $\left(250^{\circ} \mathrm{C}\right)$, split ratio (50:1), column (DB-WAX $60 \mathrm{~m} \times 0.25 \times 0.25$ ), flow (1 $\mathrm{mL} / \mathrm{min} \mathrm{He})$ and temperature program $\left(10^{\circ} \mathrm{C} / \mathrm{min}\right.$ temperature increase, 5 min incubated and $70{ }^{\circ} \mathrm{C}, 29 \mathrm{~min}$ incubated and 230 $\left.{ }^{\circ} \mathrm{C}\right)$.

\section{Preparation of probiotic yoghurts added in different ratios of Cinnamon}

Pasteurized cow's milk (3\% fat) used in the production of yogurts was purchased from the market (Dost milk, Turkey). Regular yogurt and probiotic yogurt starter cultures (Streptocus thermophilus, Lactobacillus delbrueckii subsp. bulgaricus, Lactobacillus acidophilus and Bifidobacterium animalis ssp. lactis) were obtained commercially (Maysa food, Adana, Turkey). Starter culture and cinnamon at $0 \%$ (control group), $0.3 \%$ (cinnamon 1), $1 \%$ (cinnamon 2 ) and $2.5 \%$ (cinnamon 3 ) ratios were added to pasteurized milk heated at $45^{\circ} \mathrm{C}$. Each experimental group was repeated 3 times. The amount of culture used in yogurt production and the incubation temperature were provided in according to company recommendation that produced the culture. After incubation, probiotic yogurts were matured at + starter $4^{\circ} \mathrm{C}$ for 24 hours and microbiological, chemical and sensory analyses of yogurts were performed.

\section{Microbiological Analysis}

Microbiological analyses of experimental probiotic yogurts were performed according to IDF and ISO standards (16). Pepton powder, M17, MRS, MRS-CC and TOS-MUP agar plates used in the study were commercially obtained (Merck, Turkey). In aseptic conditions, $10 \mathrm{~g}$ of each experimental yogurt was weighed in sterile bags (Sterile Stomacher Bag, VWR, Turkey) with $90 \mathrm{~mL}$ $0.1 \%$ peptone water. Homogenization of the first and dilution $\left(10^{-1}\right)$ was achieved in Stomacher (VWR, Italy). The adilution series were prepared up to $10^{-7}$. One hundred microliters were taken from each dilution and inoculated on agar plates mentioned above (17). Inoculated MRS, MRS-CC and TOSMUP media were incubated at $37^{\circ} \mathrm{C}$ in anaerobic conditions for 72 hours (Memmert, IN 110, Germany). Anaerobic conditions were provided using the anaerobic jar and related kits (Merck, Darmstadt, Germany). M17 agar plates were incubated for 24 hours at $45^{\circ} \mathrm{C}$ in aerobic conditions after inoculation. Colony counter (Interscience, Scan 100, France) was used to evaluate agar plates after incubation. Streptococcus thermophilus in M17 agar plate, Lactobacillus delbrueckii subsp. bulgaricus in MRS agar plate, Bifidobacterium animalis ssp. lactis in TOS-MUP agar plate and Lactobacillus acidophilus bacteria in MRS-CC agar plates were identified. Only 25-250 colonies presented agar plates were evaluated (17). The determined bacterial numbers were calculated as colony-forming unit (cfu)/g yogurt with the cfu formula.

\section{Chemical Analysis}

For quantitative analysis of the oil, $50 \mathrm{~g}$ of each yogurt sample was weighed (Ohaus Company, USA) and $5 \mathrm{~mL}$ ammonia (Merck 28-30\%) was added and they were mixed together. Each specimen was studied twice. For this reason, 2 butyrometers (Funke Gerber, $0.1 \%$ sensitivity) were taken and $10 \mathrm{~mL}$ of sulfuric acid (Merck 90\%, d=1.82) and $11 \mathrm{~mL}$ of prepared yogurt-ammonia mixture were added to each butyrometer. One $\mathrm{mL}$ of $\mathrm{N}$-amyl alcohol (Merck 100\%, $\mathrm{d}=0.815$ ) was added to 
each. Butyrometers were centrifuged in the Gerber centrifuge (Funke Gerber Germany, $\mathrm{T}=65^{\circ} \mathrm{C}, 1350 \mathrm{rpm}$ ) for $5 \mathrm{~min}$. After centrifugation process, butyrometers were kept in water bath (J. P. Selecta, Spain) at $63{ }^{\circ} \mathrm{C}$ for 10 minutes and centrifuged for another 5 minutes. The results were read from the butyrometer and fat ratio was calculated in percentage (18).

Some sea sand (Merck, Turkey) was added into the petri dishes for oil-free dry matter analysis and dried at $103{ }^{\circ} \mathrm{C}$ in drying-oven (Binder, ED 115, Germany). It was then cooled in a desicator and weighed on the precision scale (Ohaus, USA). Three grams from homogenized yogurt sample were transferred to the Petri box and dried in drying-oven at $103{ }^{\circ} \mathrm{C}$ for 2 hours and then cooled in a decicator. The resulting sample was weighed at the precise scale and the percentage amount was calculated by mass as $\mathrm{m} / \mathrm{m}(19)$.

Protein content analysis of experimental yogurt groups was done by formol titration method (19). Fifty g of yoghurt sample was weighed (OHAUS, USA) and $50 \mathrm{~mL}$ of destile water was added. Then $0.5 \mathrm{~mL}$ of $2 \%$ phenolphthalein (Merck, Turkey) and $2 \mathrm{~mL}$ of saturated potassium oxalate (Merck, Turkey) were added and mixed. The mixture was titrated 2 minutes later with $0.1 \mathrm{~N}$ of sodium hydroxide $(\mathrm{NaOH})$ (Merck, Turkey) until it slightly got pink. Then $10 \mathrm{~mL}$ of formaldehyde (Merck, Turkey) was added to the mixture and mixed. After waiting $1 \mathrm{~min}$, the mixture was titrated with $0.1 \mathrm{~N} \mathrm{NaOH}$ until the pink color was obtained again. Finally, the amount of protein in yogurts and the amount of $0.1 \mathrm{~N} \mathrm{NaOH}$ solution titrated were calculated.

For titration acidity determination, $10 \mathrm{~g}$ of samples from experimental yogurt groups were weighed and $10 \mathrm{~mL}$ of distilled water was added. $0.5 \mathrm{~mL}$ phenolphthaline (Merck, Turkey) was added to the mixture and titrated with $0.1 \mathrm{~N} \mathrm{NaOH}$ until it received a pink color that did not disappear for about 30 seconds. Titration acidity was calculated with the amount of $0.1 \mathrm{~N} \mathrm{NaOH}$ used (18).

The $\mathrm{pH}$ values of experimental yogurt groups were measured with a calibrated heat-sensor $\mathrm{pH}$ meter (Mettler-Toledo, Switzerland) containing a xerolyt polymer electrolite filled electrode (20).

\section{Sensory Analysis}

The probiotic yogurts produced were evaluated by the project researchers as blind according to the Turkish Standards $(19,21)$. In general, yogurt must comply with TS 1330 Yogurt Standard in terms of appearance, consistency, smell and taste and must receive at least 4 points from each feature and 16 points in total.

\section{Statistical Analysis}

Data from microbiological and chemical analyses of experimental probiotic yogurts were evaluated using the SPSS 16.0 statistical package program. The Mann-Whithney $U$ test was performed to compare the result of each cinnamon group with the control group and to determine whether there was a statistical difference between them. $\mathrm{P}$ value $<0.05$ was considered statistically significant. The data obtained from the sensory analysis were calculated as total points for each group.

\section{Results}

The volatile oils found in powdered cinnamon are listed as follows from high to low amounts, respectively: cinnamaldehyde, alphaCoapene, caryophyllene, eucalyptol and others. Cinnamon powder volatile oil GC-MS chromatogram is shown in Figure 1.

The number of Streptococcus thermophilus, a yogurt culture bacterium, was higher in the control group than in cinnamondoped yogurt ( $1 \%$ and $2.5 \%$ ) groups (Figure $2 \mathrm{a}$ ). On the other hand, the number of these bacteria decreased in yogurts due to the increased cinnamon rate.The number of Lactobacillus delbrueckii subsp. bulgaricus, a yogurt culture bacterium, was similar in the control group and in $1 \%$ and $2.5 \%$ cinnamondoped yogurt groups (Figure $2 \mathrm{~b}$ ). Only a statistically significant difference was found between the control group and cinnamon 1 $(0.3 \%)$ group $(\mathrm{p}<0.05)$. The number of Bifidobacterium animalis ssp. lactis was significantly higher in the control group than the cinnamon groups $(\mathrm{p}<0.05)$ (Figure $2 \mathrm{c})$. There was no statistically significant difference between the cinnamon groups. Lactobacillus acidophilus, another probiotic bacterium used in the study, was statistically significantly higher in the control group compared to the cinnamon-added yogurts $(\mathrm{p}<0.05)$ (Figure $2 \mathrm{~d}$ ).

The results of the chemical analyses of probiotic yogurt groups are presented in Table 1 with average amounts and standard deviations of $\%$ fat, $\%$ non-fat dry matter, $\%$ protein, $\%$ lactic acid and $\mathrm{pH}$ values together. The fat ratio of the control group $(3.3 \pm 0.1 \%)$ was found to be higher than all cinnamon groups. There was no statistically significant difference between the results. Cinnamon-added $(0.3 \%)$ yogurts had the lowest fat-free dry matter ratio, while the fat-free dry matter ratio also increased due to the increased cinnamon ratio. Statistically significant difference was found between all groups $(p<0.05)$. The protein ratios of all yogurt groups, including the control group, were the

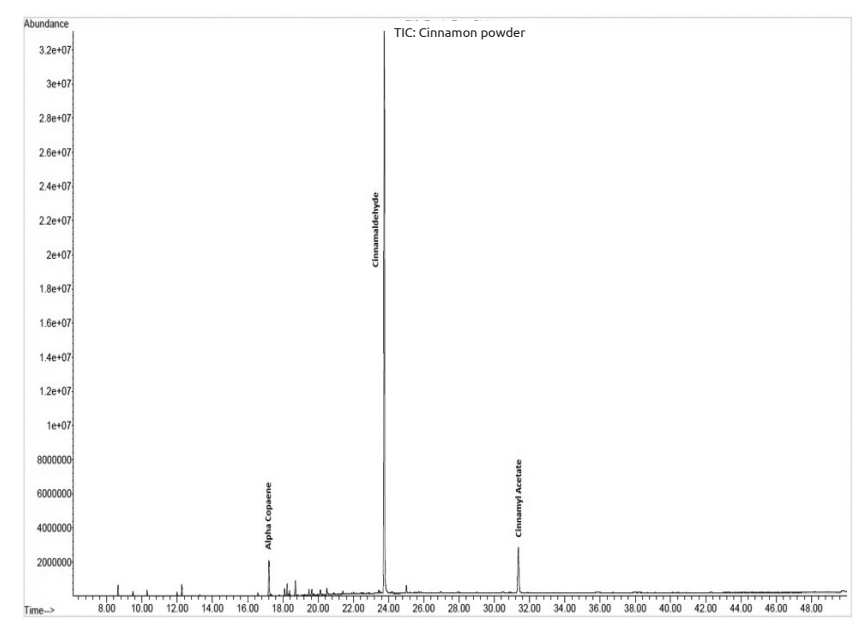

Figure 1. GC-MS chromatogram of volatile oil of cinnamon powder 
same. Titration acidity of the control group was significantly higher than all cinnamon groups $(\mathrm{p}<0.05)$. On the other hand, titration acidity decreased due to the increased cinnamon rate. The $\mathrm{pH}$ value of the control group was significantly lower than the cinnamon groups $(\mathrm{p}<0.05)$. The $\mathrm{pH}$ value of yogurts increased due to the increased cinnamon ratio $(4.06 \pm 0.08$, $4.07 \pm 0.06$ and $4.27 \pm 0.01$ respectively).

When the sensory analysis of yogurts was scored, the control group received the highest score (160 points) in total, while the closest value to this score was in $0.3 \%$ cinnamon-added yogurt. Sensory analysis scores of yogurts with $1 \%$ and $2.5 \%$ cinnamon addition were found to be close to each other.

\section{Discussion}

Probiotics are microorganisms that are alive and can produce substances that encourage the reproduction of other microorganisms (22). However, the effects of these microorganisms depend on the strain to which they belong and the dose in the product in which they are found. On the other hand, the survival, growth and viability of these microorganisms are affected by the stages of production of probiotic food (23). It has been reported in various in vitro, in vivo and human studies that probiotic microorganisms in the product must be more than $1.0 \times 10^{6} \mathrm{cfu} / \mathrm{g}$ in order for a probiotic food to have therapeutic effect (24). In our study, the number of probiotic bacteria was more than $1.0 \times 10^{6} \mathrm{cfu}$ in each gram of all produced probiotic yogurts.

Cinnamon is widely used in the food industry because of its antioxidant effects, colour and flavoring properties, as well as in the medical, cosmetic, perfumery and nutraceutical industries (13). Scientific studies also report that cinnamon has antibacterial effect besides its many bioactivities $(12,13)$. On the other hand, cinnamon increases the safety of food products against foodborne pathogens and food-spoiling bacteria due to its antimicrobial

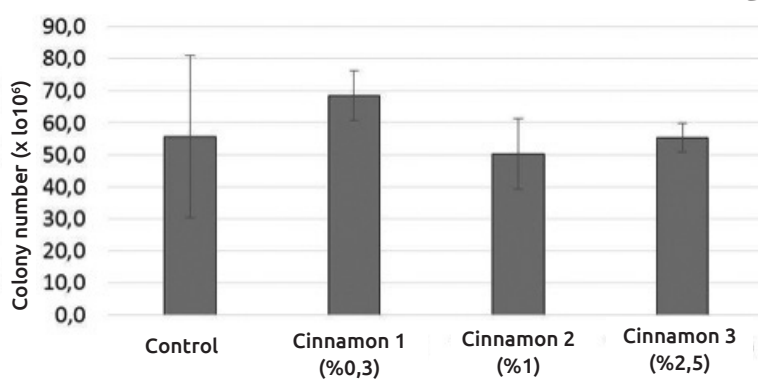

b

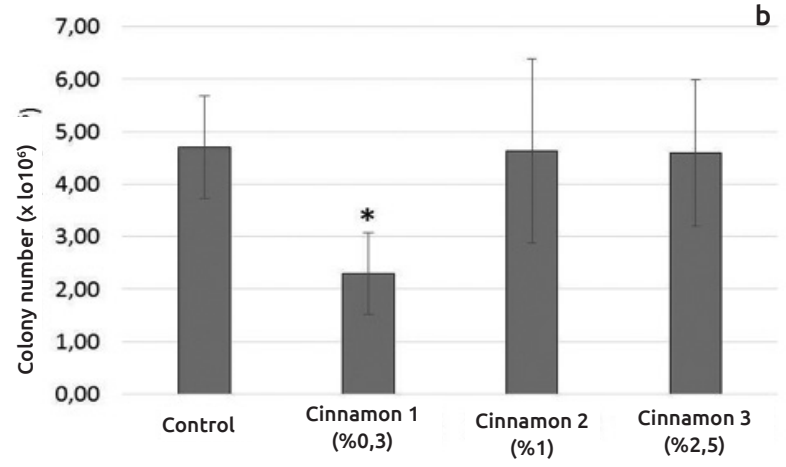

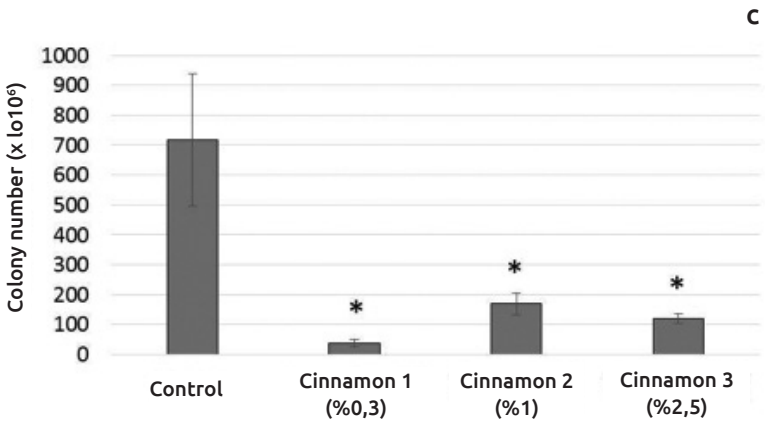

d

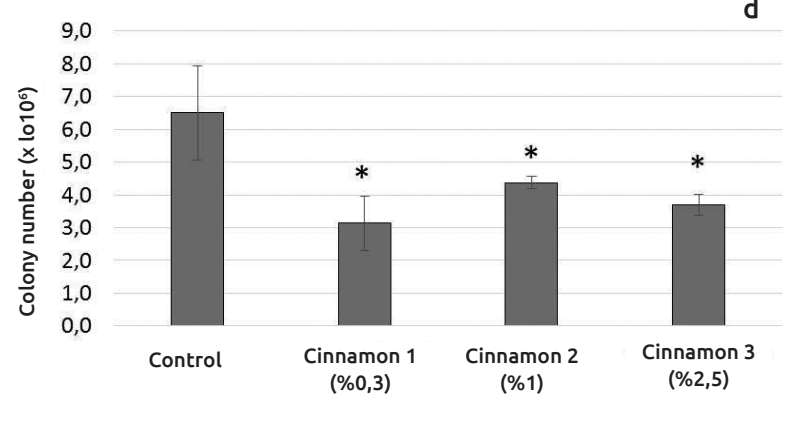

Figure 2. The bacteria counts in probiotic yogurt groups are determined as colony forming unit. a) Streptococcus thermophilus, b) Lactobacillus delbrueckii subp. bulgaricus, c) Bifidobacterium animalis ssp. lactis and d) Lactobacillus acidophilus. * Differences between control group and cinnamon groups are statistically significant $(p<0.05)$

Table 1. Fat, fat-free dry matter and protein percentages and $\mathrm{pH}$ value of control and cinnamon added probiotic yogurt groups are shown as mean \pm SD.

\begin{tabular}{|c|c|c|c|c|}
\hline & Control (0\%) & Cinnamon $(0.3 \%)$ & Cinnamon 2 (1\%) & Cinnamon 3 (2.5\%) \\
\hline Fat $(\mathrm{m} / \mathrm{v} \%)$ & $3.3 \pm 0.1$ & $3.2 \pm 0.05$ & $3.2 \pm 0.05$ & $3.2 \pm 0.05$ \\
\hline Fat-free dry matter (m/m \%) & $8.15 \pm 0.01$ & $8.08 \pm 0.02$ & $8.24 \pm 0.02$ & $9.53 \pm 0.02$ \\
\hline Protein (m/m) & $3.54 \pm 0.02$ & $3.54 \pm 0.02$ & $3.54 \pm 0.01$ & $3.54 \pm 0.02$ \\
\hline Titration Acidity ( $\mathrm{m} / \mathrm{m} \%$ )(acidity in terms of lactic acid) & $0.97 \pm 0.05$ & $0.87 \pm 0.05$ & $0.86 \pm 0.02$ & $0.74 \pm 0.01$ \\
\hline $\mathrm{pH}$ & $3.98 \pm 0.08$ & $4.06 \pm 0.06$ & $4.07 \pm 0.05$ & $4.20 \pm 0.01$ \\
\hline
\end{tabular}


and antibacterial properties and extends shelf life (12). This is why cinnamon is an effective food preservative. The inhibiting effect of cinnamon on the development of Staphylococcus aureus, which is particularly contagious to food, is due to its various chemicals contained in cinnamon (25). The most important chemical component in cinnamon is cinnamaldehyde, which has been reported to inhibit Staphylococcus aureus. As a result of GCMS analysis of the cinnamon used in our study, cinnamaldehyde was found highest.

The antibacterial effect of cinnamon on gram-positive and gramnegative bacteria that cause infectious diseases in humans and on Salmonella typhimurium, S. aureus, E. coli, Arcobacter butzeiri and Arcobacter skirrowii that are food and cosmetic disrupting agents and lead to major public health problems has been shown in studies (12). In our study, for the first time, the effect of cinnamon spice on yogurt and probiotic yogurt starter cultures was investigated. In all cinnamon groups, the number of $B$. animalis ssp. lactis and L. acidophilus probiotic bacteria decreased statistically significantly compared to the control group. The results of a study performed with L. rhamnosus, a probiotic bacterium, supports our findings. The number of L. rhamnosus was found to be lower in the cinnamon volatile oil-added $(0.04 \%)$ yogurts compared with the control group (26). In our study, the number of $L$. delbrueckii subsp. bulgaricus, a yogurt culture bacterium, increased as the ratio of cinnamon increased and the number of this bacterium was found to be lowest in the yogurt containing the lowest level of cinnamon (0.3\%). Also, the ratio of cinnamon added affected the sensory analysis result of probiotic yogurts. Sensory analysis evaluation scores and number of $S c$. thermophilus were similar in the control group and cinnamon $1(0.3 \%)$ group. In a study, a positive correlation was found between sensory quality of yoghurts and the number of Sc. thermophilus, which supports our findings (27). In the same study, was reported that the number of B. bifidum had a positive effect on the sensory quality of yogurt, and in our study, the sensory quality of the control group and the number of $B$. animalis ssp. lactis in the control group was found to be higher than other groups.

The fat ratio of probiotic yogurts produced in the study was higher than the fat ratio of milk used $(3 \%)$. The average fat ratio of all groups was $\% 3.2 \pm 0.5 \%$. It has been observed that the fat ratios of yogurt groups to which cinnamon was added was not affected by cinnamon. A study by Lindasari (28) found that the fat ratio decreased as the rate of cinnamon extract added increased in probiotic yogurts made from goat's milk with 3\%, $4 \%, 5 \%$ cinnamon extract added (fat ratios were $6.40 \pm 1.22 \%$, $6.30 \pm 0.54 \%$ and $5.70 \pm 1.49 \%$, respectively). The fat-free dry matter ratios of cinnamon-added probiotic yogurts were higher than the control group and the average of all groups was $8.62 \pm 0.69 \%$. A study of probiotic yogurts produced by adding prebiotics also supports our results (29). The protein ratios of the yogurts we produced were the same (3.54\%). This can be attributed to very low protein content in cinnamon (30). On the other hand, the study of probiotic yogurts with cinnamon extract added showed that there was no correlation between the groups in terms of protein ratio $(4.03 \pm 0.32 \%, 3.84 \pm 0.38 \%$ and $4.16 \pm 0.69 \%$, respectively) (28). Titration acidity was lower in cinnamon groups compared to the control group and a decrease was found due to cinnamon ratio $(\% 0.97 \pm 0.05$ in control group, $\% 0.87 \pm 0.05$ in cinnamon $1, \% 0.86 \pm 0.02$ in cinnamon 2 and $\% 0.74 \pm 0.01$ in cinnamon 3$)$. In a study, it was reported that no change in acidity and $\mathrm{pH}$ of probiotic yogurts produced from cow and camel milk with cinnamon added was observed (31). In another study, titration acidity and $\mathrm{pH}$ values confirmed each other $(1.66 \pm 0.15 \%, \quad 1.69 \pm 0.01 \%$ and $1.87 \pm 0.12 \%)(28)$. In our study, the $\mathrm{pH}$ value of the control group $(3.98 \pm 0.08)$ was significantly lower than the cinnamon groups. In addition, the $\mathrm{pH}$ value of cinnamon groups increased due to the increased rate of cinnamon. On the other hand, in probiotic yogurts made from goat's milk with cinnamon extract (3\%, 4\% and 5\%), $\mathrm{pH}$ values were lower compared to the control group, regardless of the rate of cinnamon extract (28).

Cinnamon 1 and 2 groups with similar acidity values were also found to be close in total acceptability scores as a result of sensory analysis. In a study of probiotic yogurts with banana additives, it was reported that there was an association between acceptability of yogurts as a result of analysis of sensory properties of yogurts and acidity of yogurts (27).

\section{Conclusion}

As a result, cinnamon added to probiotic yogurt has been shown to improve the microbial and chemical quality of the product and to have limited positive effects on sensory properties.

\section{Ethics}

Ethics Committee Approval: The study was approved from the Non-Interventional Research Ethics Committee (20.03.2018, number: 54022451-050.05.04).

Peer-review: Externally peer-reviewed.

\section{Authorship Contributions}

Consept: A.G.B., Design: M.G.B., A.G.B., Data Collection or Processing: A.G.B., M.G.B., Analysis or Interpretation: A.G.B., M.G.B., Literature Search: A.G.B., Writing: A.G.B., M.G.B.

Conflict of Interest: No conflict of interest was declared by the authors.

Financial Disclosure: This study was supported by Bezmialem Vakif University Scientific Research Project Coordination Unit (project no:1.2017/14).

\section{References}

1. Kopp-Hoolihan L. Prophylactic and therapeutic uses of probiotics: a review. J Am Diet Assoc 2001;101:229-41.

2. Roberfroid MB. Prebiotics and probiotics: are they functional foods? Am J Clin Nutr 2000;71:1682-7.

3. İnanç N, Şahin H, Çiçek B. Probiyotik ve Prebiyotiklerin Sağlık Üzerine Etkileri. Erciyes Tip Dergisi 2005;27:122-7. 
4. Begum PS, Madhavi G, Rajagopal S, Viswanath B, Razak MA, Venkataratnamma V. Probiotics as Functional Foods: Potential Effects on Human Health and its Impact on Neurological Diseases. Int J Nutr Pharmacol Neurol Dis 2017;7:23-33.

5. Türk Gıda Kodeksi Etiketleme Yönetmeliği/Ek-15, Sağlık Beyanları ve Beyan Koşulları. Available from: URL: http://www.resmigazete. gov.tr/eskiler/2017/01/20170126M1-5.htm 05.03.2018.

6. Fernandes CF, Shanani KM, Amer MA. Therapeutic role of dietary lactobacilli and lactobacilli fermented dairy products. FEMS Microbiol Rev 1987;3:343-56.

7. Tekinşen OC. Yoğurt yapımı. Veteriner Hekimler Derneği Dergisi 1976;46:29-36.

8. Ranadheera RDCS, Baines SK, Adams MC. Importance of food in probiotic efficacy. Food Res Int 2010;43:1-7.

9. Sanches B, De Los Reyes-Gavilàn CG, Margolles A, Gueimonde, M. Probiotics fermented milks: present and future. Int J Dairy Technol 2009;62:472-83.

10. Lourens-Hattingh A, Viljoen BC. Yoghurt as probiotic carrier food. Int Dairy J 2001;11:1-17.

11. Geier MS, Butler RN, Howarth GS. Probiotics, prebiotics and synbiotics: a role in chemoprevention for colorectal cancer? Cancer Biol Ther 2006;5:1265-9.

12. Nabavi SF, Di Lorenzo A, Izadi M, Sobarzo-Sánchez E, Daglia M, Nabavi SM. Antibacterial effects of cinnamon: From farm to food, cosmetic and pharmaceutical industries. Nutrients 2015;7:7729-48.

13. De La Torre JE, Gassara F, Kouassi AP, Brar SK, Belkacemi K. Spice use in food: Properties and benefits. Crit Rev Food Sci Nutr 2017;57:1078-88.

14. Akarca G, Kahraman A, Tomar O. Değişik Oranlarda Tarçın İlave Edilmiş Pastörize Sütlerde Raf Ömrünün Değişimi. AKÜ FEMÜBİD 2015;15:1-9

15. Hammad AM. Antimicrobial Effect of Cinnamon and Clove on Staphylococcus aureus in Milk and Yoghurt. AJVS 2016;48:1-6.

16. Van de Casteele S, Vanheuverzwijn T, Ruyssen T, Van Assche P, Swings J, Huys G. Evaluation of culture media for selective enumeration of probiotic strains of lactobacilli and bifidobacteria in combination with yoghurt or cheese starters. Int Dairy J 2006;16:1470-6.

17. Süle J, Körösi T, Hucker A, Varga L. Evaluation of culture media for selective enumeration of bifidobacteria and lactic acid bacteria. Braz J Microbiol 2014;45:1023-30.

18. Tekinşen OC, Atasever M, Keleş A, Tekinşen KK. Süt, Yoğurt, Tereyağı, Peynir Üretim ve Kontrol. ISBN: 975-448-123-3. Konya: Selçuk Üniversitesi Basımevi; 2002.
19. Türk Standartları: TS 1330/ Nisan 2006. Available from: https:// intweb.tse.org.tr/standard/standard/Standard.aspx?0811180511151 0805110411911010405504710510212008811104311310407310 1082118082065051084077051113069 05.03.2018.

20. Cemeroğlu BS. Gıda Analizleri. ISBN: 978-605-63419-3-9. Ankara: Bizim Grup Basımevi; 2013.

21. Türk Standartları: TS 1018/Nisan 2002. Available from: https:// intweb.tse.org.tr/standard/standard/Standard.aspx?0811180511151 0805110411911010405504710510212008811104311310407310 2053056105103114116119067119097_05.03.2018.

22. Lilly DM, Stillwell RH. Probiotics: growth-promoting factors produced by microorganisms. Science 1965;147:747-8.

23. Kolacek S, Hojsak I, Canani RB, Guarino A, Indrio F, Orel R, et al. Commercial probiotic products: a call for improved quality control. A position paper by the ESPGHAN Working Group for Probiotics and Prebiotics. J Pediatr Gastroenterol Nutr 2017;65:117-24.

24. Panghal A, Janghu S, Virkar K, Gat Y, Kumar V, Chhikara N. Potential Non-Dairy Probiotic Products-A Healthy Approach. Food Biosci 2018;21:80-9.

25. Winias S, Retno A, Magfiroh R, Rayahu R. Effect of cynammyldehyde from cinnamon extract as a natural preservative alternative to the growth of Staphylococcus aureus bacteria. J Trop Infect Dis 2011;2:38-41.

26. Moritz CMF, Rall VLM, Saeki MJ, Junior AF. Inhibitory effect of essential oils against Lactobacillus rhamnosus and starter culture in fermented milk during its shelf-life period. Braz J Microbiol 2012; 43:1147-56.

27. Çakmakçi S, Çetin B, Turgut T, Gürses M, Erdoğan A. Probiotic properties, sensory qualities, and storage stability of probiotic banana yogurts. Turk J Vet Anim Sci 2012;36:231-7.

28. Lindasari F. Characteristic of Goat's Milk Probiotic Yoghurt with Addition of Cinnamon Extracts as Flavor. Thesis, Bogor-Indonesia: Department of Production Science and Technology Livestock Faculty of Livestock Institute Agricultural Bogor; 2013.

29. Yeşilçubuk Ş. Saccharomyces Boulardii Kullanarak Probiyotik Yoğurt Üretimi Ve Bazı Prebiyotiklerin Yoğurtların Çeşitli Nitelikleri Üzerine Etkisinin İncelenmesi. Yüksek Lisans Tezi, İstanbul: İstanbul Teknik Üniversitesi, Fen Bilimleri Enst. 2014.

30. United States Department of Agriculture Agricultural Research ServiceUSDA Food Composition Databases. Available from: https:// ndb.nal.usda.gov/ndb/search/list?qlookup=02010 05.03.2018.

31. Shori AB, Baba AS. Cinnamomum verum improved the functional propertiesof bioyogurts made from camel and cow milks. Journal of the Saudi Society of Agricultural Sciences 2011;10:101-10. 